\title{
Redaktionelt forord til "Temanummer om DOI og OJS"
}

Vi har valgt at udgive dette temanummer for at sikre, at vores tidsskriftredaktioner lettere kan integrere Digital Object Identifier (DOI) i deres artikelopsætning. ${ }^{1}$

Temanummeret indeholde følgende artikler/vejledninger:

1: Hvordan indsætter redaktøren/tidsskriftschefen referencer i overensstemmelse med CrossRef's krav? Artiklen viser, hvor man skal indsætte referencer i OJS, så de bliver en del af den søgbare metadata og lever op til de krav CrossRef stiller for at tildele DOI'er.

2: Hvordan indsætter forfatteren litteraturlister i OJS?

Vejledning i hvor forfatteren indskriver sin litteraturliste, så den indgår som del af metadata.

3: Hvordan får man forfatterne til at indsætte DOI i deres kildehenvisninger?

Artiklen viser, hvordan man i opsætningen af sit tidsskrift kan gøre forfatteren opmærksom på, at få indsat DOI, når det er relevant.

4: Hvordan sikrer man, at publiceringsdatoen er korrekt?

For at registrere en artikel, skal publikationsdatoen anføres. Vær opmærksom på, at datoen er korrekt! Hvis datoen mangler, kan artiklen ikke få tildelt et DOI af CrossRef. Denne artikel viser, hvordan man som redaktør let kan sikre, at oplysningerne er korrekte.

5: Hvordan indsættes DOI-navnet korrekt i en litteraturliste?

Denne vejledning viser eksempler, hentet fra de mest udbredte output styles, som tidsskifterne kan bruge til at hjælpe forfatterne med at indsætte DOI det rigtige sted i referencen.

Jesper Boserup Thestrup og Niels Erik Frederiksen, marts 2015

\footnotetext{
${ }^{1}$ Læs mere om DOI og CrossRef her: Thestrup, J., Frederiksen, N.E. (2014). DOI, CrossRef og OJS-servere. OJS På Dansk,
} 5(4) http://dx.doi.org/10.7146/ojssb.v5i4.19826 